\title{
"Colonize and Cholerize": an attempt to decipher the ambiguity of the literary representation of the cholera epidemics in Nineteenth Century India
}

\author{
Arijit Goswami \\ Assistant Professor, Department of English, Gorubathan Government College, Kalimpong, \\ E-mail: arijit.goswami8o@gmail.com
}

\begin{abstract}
The modus operandi of categorising European and especially British authors as representative of the hegemonic colonial enterprise that subjugated the Indian sub-continent for nearly two hundred years is a common analogy while dealing with the colonial era. The seemingly simplistic logic is problematised, when a British author, closely related to the ruling administrative set-up voices dissent, whereas the colonised intelligentsia fails to register minimal protest in their literary works. The article would try to decipher the anti- orientalist discourse with special reference to the literary representation of cholera epidemics in Fanny Parkes's Wanderings of a pilgrim in search of the picturesque (1850), during the patriarchal- colonising enterprise in vogue and envisage to compare Lal Behari Day's Folktales of Bengal (1883), which fails to express the reality of an epidemic-devastated land and displeasure of the commoners towards the ruling class for their inept handling of the epidemics.
\end{abstract}

Keywords: Colonization, Cholerize, Dissent, Anti-orientalism

\section{Introduction}

India had been ravaged by cholera epidemics from early eighteenth century, with the period 181721 being the initial point of reference as the impact that epidemics had upon the history of the subcontinent and later, most of the world reached an unforeseen height during this period. The epidemic which began in the town of Jessore in 1817 had spread by sea and land to other countries in Asia, Africa, Europe and even America. The scholars like David Arnold, Niels Brimnes, Michael Zeheter et al., have normally dealt with the data available about cholera epidemics in specific areas but rarely on the human connect. The data do not portray what the 'common' colonised people of India as well as the 'not-so-common' colonising British East India Company employees, initially, and later, the personnel of the British Crown had to undergo during the grim epidemic days. This article seeks to find whether the epidemics had been an equaliser of sorts when it came to the basic human urge to exist, moving beyond the binary of the 'coloniser' and the 'colonised'.

\section{Administrative and Societal Reaction}

The reaction of the East India Company and its personnel to the cholera epidemic during the initial years was conservative and even at times ameliorative primarily due to the fact that the Company did not want to initiate any negative response from the newly acquired land and its

(c) AesthetixMS 2020. This Open Access article is published under a Creative Commons Attribution Non-Commercial 4.0 International License (http://creativecommons.org/licenses/by-nc/4.0/), which permits non-commercial re-use, distribution, and reproduction in any medium, provided the original work is properly cited. For citation use the DOI. For commercial re-use, please contact editor@rupkatha.com. 
natives. 'The stringency of quarantine and sanitary cordons to protect the army establishments and the European residential area were later additions to the epidemic management scenario, especially post-1857. It is interesting to note that the heavy-handedness of the post-1857 measures to control epidemics inflamed political tensions and culminated in panic, strikes and violence' (Chandravarkar, 1992). Europeans regarded cholera as a contagious pestilential disease which arose due to the unhealthy climate of India and a total lack of sanitation. "Everywhere it travelled, cholera became synonymous with poverty, squalor, and neglect.” (Hamlin, 2009)

Before the use of epithets like ' Epidemic', 'Asiatic', and 'Indian', the disease, of course, existed in India and especially in the port cities. The disease which was charecterised by violent purging mostly ending in death had long been recognised by the Indian society and thus the local deities like Ola Bibi or 'the lady of the flux' came into existence in Calcutta even before the colonisers faced the brunt of the disease. The title 'bibi' suggests the syncretisation of HinduMuslim faiths and the growth of a new deity for protection from cholera though the presence of a similar deity named 'Ola Chandi' can be traced in parts of deltaic Bengal. Other disease deities, including the smallpox goddess Siitalā, had a similarly mixed following and were the subjects of devotional literature and songs.

The presence of Ola Bibi in the precincts of Calcutta was minimal initially but by 1720 a new temple was built and later renovated with money received from a British resident $\mathrm{Mr}$. Duncan, near Kalighat, as thanksgiving, for the survival of his Indian Muslim wife from cholera. The followers of Ola Bibi though primarily from the economically and socially downtrodden yet, some wealthy Hindus of both sexes were also present and attendance crossed caste, religious, and racial boundaries, and included 'Native Portuguese, Musalmans, and even Chinese'. (Naskar, 1999). According to Dipesh Chakrabarty (2012), 'the knee-jerk reaction of society on the whole, allowed communities to rediscover a lost sense of unity. The whole situation of coloniser and colonised thus faded to the periphery when humanity faced the struggle of existence against a common seemingly indestructible foe'. The conservative, patriarchal and hegemonic administrative responses of the British Raj was thus clearly at odds to the common European folk who came to India to make a living.

\section{Literary Reactions with special reference to Fanny Parkes' Wanderings of a pilgrim in search of the picturesque (1850)}

The literary world of nineteenth century India had contributions both from the colonisers as well as the colonised. The telescoping effect and the oriental gaze was omnipresent in the literary output but to categorise creativity due to a pre-ordained and defined partisan identity is misleading. It is interesting to note that the educated urban Indian of the then existent metropolis like Calcutta and the mainstream literature in vogue were silent about the epidemics and the lack of proper administrative measures to tackle the same. It was much later that novelists like Sarat Chandra Chatterjee depicted the effect of epidemic on the general population of rural Bengal in his novels Panditmashai (1914), Pallisamaj (1916), Srikanta (1917) but the immediate response was nearly unheard except for a few vernacular news reports:

Although the disease had a devastating impact on many communities, Indian responses aimed to restore order and unity rather than to challenge British rule. Indeed, there is little evidence to suggest that cholera was attributed to the British or other foreigners. (Harrison, 2009, p.48) 
It is interesting to note that though the native voice was relatively silent, a voice of protest emanating from the colonial- British literary world can be traced in Fanny Parkes's Wanderings of a pilgrim in search of the picturesque (1850). Fanny Parkes, a 'coloniser' by identity was able to break the taboo of the oriental gaze and put forward her own feelings which can be seen to be at odds with the traditional patriarchal and hegemonic ideas of the colonisers, as she stayed and travelled extensively in India from 1822-1846. In contrast to the Orientalist notion of cholera's and later India's association with 'poverty, squalor and neglect', the initial response of Fanny Parkes on arriving at Calcutta is highly interesting:

On arriving in Calcutta, I was charmed by the climate; the weather was delicious; an I thought India a most delightful country ... could I have gathered around me the dear ones I had left in England, my happiness would have been complete." (Volume I, Chapter IV, Page: 21)

When the gamut of literature, during the first-half of the nineteenth century chose to be silent about the cholera epidemics, there are fifty-three references to cholera and its effects in Wanderings of a pilgrim in search of the picturesque(1850) with an entire chapter depicting her experience of facing cholera at Prayag/ Allahabad (Volume I, Chapter XXV, pp. 280-292). She mentions repeatedly that cholera made no distinction among human beings, be it the coloniser or the colonised. She referred to the state of cholera in Prayag:

...the Europeans are all suffering with fever and ague and rheumatism. The natives, in a dreadful state, are dying in numbers daily of cholera; two days ago, seventy-six natives in Allahabad were seized with- cholera- of these, forty-eight died that day! The illness is so severe that half an hour after the first attack the man generally dies; if he survives one hour it is reckoned a length of time." (Volume I, Chapter XXV, p. 280)

The plight of the Indians is further stated in details:

The natives in the bazar and surrounding villages suffer shockingly from cholera, and you can scarcely go into any of the thoroughfares to the ghats, without seeing several dead bodies being carried to the Ganges. (Volume I, Chapter XXV, p. 285)

The fact that she is critical of the inept handling of the epidemics in Indian sub-continent is evident in multiple instances. The method of nearly abandoning the personnel of East India Company at a critical juncture when faced with the situation of life and death during the cholera epidemic for mere economic gain of a select few of London can be traced in her words:

The interference with the Company's charter, that people in England may drink their tea cheaper, which result, however, appears doubtful, and that the surplus population may come out to colonize, and cholerize, has done the Service no benefit. Economy is still the rage, and we of the present day have nothing to look to but to but the pension from our Civil Annuity Fund, after twenty-two years' residence, of £1ooo, for which we have to pay one-half, 50,000 rupees, when we can hoard up as much...and if they have subscribed for twenty-one years and eleven months, the whole goes to the fund, principal and interest. (Parkes, Volume I, Chapter XXV, p. 290)

These are not the words of a coloniser, but a commoner who had to come to India, an unknown spatial domain, and face the hardships, with no compassion from the mercantile British people at the helm of administrative and economic affairs. There is also an interesting use of the word "hoard", the system of apathy which knows no geographical and cultural bounds turns even 
a common and supposedly honest employee of East India Company, the 'coloniser', into a hoarder, much against his or her own wish.

Parkes is critical of the inept handling of epidemics by the then British administration and the undermining of general health protocol for petty economic gains and even dispels the oriental notion in vogue that all epidemics in India are caused by the inclement weather and the abundance of filth and squalour:

April 6th- The small pox is making great ravages; some of our friends have fallen victims. Lord William Bentinck did away with the vaccine department, to save a few rupees; from which economy many have lost their lives. It is a dreadful illness, the small pox in this country. People are in a fright respecting the plague; they say it at Palee and has approached the borders of the Company's territories; we have fevers, cholera and deadly illnesses enough without the plague it is to be trusted that will not be added to the evils of the climate. (Parkes, Volume II, p.110)

Her reference to the indigenous method of treating cholera is subtly referred to: "Every country hath its fashions" (Volume I, Chapter XXV, p. 281). The lack of confidence of the British medical knowledge to handle a new disease like cholera with symptoms still unknown to the western medical fraternity is contrasted with the native knowledge of cholera treatment can be traced in her words:

Our medical adviser said, the treatment was, 'to give forty measured drops of laudanum in a glassful of brandy and water every time the bowls are moved, which is preferable to giving a greater quantity, as that would produce drowsiness. You give opium to abate pain and stop the sickness, not to dull the senses, which are too dull already. After the first few evacuations, all that follow are like pipe clay and water,- one of the sign of cholera. 'Spirits of hartshorn in water is found very beneficial to the natives. Colonel Gardner said,' Half of wine glass of the juice of onions, rubbed up with ginger, red and black pepper, and garlic, I have seen administered in desperate case of cholera with great success. (Parkes, Volume I, p.203)

\section{Literary Reaction of Indian Intelligentsia: Lal Behari Day's Folk Tales of Bengal (1883)}

The political ideology or the social status did not quench the voice of protest of Parkes but the reaction of the Indian intelligentsia, especially of Bengal, which had seen its socio-economicliterary Renaissance in early nineteenth century failed to protest. Even the words of the abject common people of the land, the rural world with its own vivacity and liveliness in the form of folklore seemingly lost its spirit of enquiry and protest when canonized through publication.

Folklore, an integral part of the pre-colonial society, was an inherent part of the theory and praxis of the entire society including the intellectuals and masses. The problem was genuine as folk-texts were oral in nature and hence embodied a sense of independence and fluidity that can be rarely achieved by mainstream literature. The fluidity of folk-literature paved the way of its recognition as a method of resistance against the colonisers throughout human history. The British understood the immense energy that folk-literature embodied and thus envisaged to get them printed. When a folk-text is printed, its features and language gets bounded within the boundary of hegemonic literary canon, and thereby looses the liveliness of performance, which is a basic feature of folk-lore. In a way the folk-tales represent the imaginative realism of the common people who existed beyond the realm of Macaulayian India. Once printed, an oral text 
was canonized and it lost all the features that proved its vibrancy and evolutionary existence. The colonial enterprise always endeavoured to use the tradition of the colonised and subvert it for strengthening their cultural domination through the distilled and deviated form of long-existent critical norms and praxis; with India the status was no different. The British wanted to control the reading practices of the natives by controlling the printed canon in early part of the nineteenth century.

In 1818, Mountstuart Elphinstones, who was to later become the Governor of Bombay, submitted a report on the literate practice of the colony:

...Books are scarce, and the common ones probably ill chosen; but there exist in the Hindu languages many tales and fables that would be generally read, and that would circulate sound morals. There must be religious books tending more directly to the same end. If many of these are printed and distributed gratuitously, the effect would without doubt, be great and beneficial. It would however be indispensible that they should be purely Hindu. We might silently omit all precepts of questionable morality, but the slightest infusion of religious controversy would secure the failure of the design. (Naregal, 2001, p.151)

Rev. Lal Behari Day (1824-1894) in the Preface to his Folktales of Bengal (1883), the first collection of Bengali folktales to be translated, compiled and published as a book, clearly states the same rationale behind his literary enterprise:

... Captain R. C. Temple, of the Bengal Staff Corps, son of the distinguished Indian administrator Sir Richard Temple, wrote to me to say how interesting it would be to get a collection of those unwritten stories which old women in India recite to little children in the evenings, and to ask whether I could not make such a collection...I believed that the collection suggested would be a contribution, however slight, to that daily increasing literature of folk-lore and comparative mythology which, like comparative philosophy, proves that the swarthy and half-naked peasant on the banks of the Ganges is a cousin, albeit of the hundredth remove, to the fair-skinned and welldressed Englishman on the banks of the Thames, I readily caught up the idea and cast about for materials. (Day, 1883, Preface)

Day openly acknowledges the supremacy of the British and asserts that his attempt is to lend a sense of equanimity on the basis of being human beings. He neither resists the colonisers attempt to formulate the Indian heritage as well as assert his own Indian identity. He never questions the British governance over the lack of empathy towards the Indian people and attempts to take his readers into the far-forlorn lands of nawabs and their zamindars. He comments:

I heard many more stories than those contained in the following pages; but I rejected a great many, as they appeared to me to contain spurious additions to the original stories which I had heard when a boy. I have reason to believe that the stories given in this book are a genuine sample of the old stories told by old Bengali women from age to age through a hundred generations. (Day, 1883, Preface)

This sense of appropriation makes us inquisitive about those "many more" oral narratives that were disavowed from the mainstream Bangla literary Canon along with the Dalimkumars, Phakir Chands and Prince Soburs whom Day had immortalised in his collection. Expressions like "genuine" and "spurious additions" represents the subjective unwillingness of the author to accept an alternative version of narrative that might challenge the pre-conceived hegemonic and colonial nature of the enterprise. A subtle glance at Day's Folktales would show us that he is apparently 
trying to romanticise and alienate the words that arise from the lore of the then colonised land by sending his readers to the realm of imagination ruled by the Raja, with his queens Duo and Suo, untouched by the Company and the British Empire. The references to socio-economic realities of Bengal clearly show that the time of reference is distinctly Sultanate and Nawabi Bengal. The surprise is that there are no tales of djinns but reference to brahmadaitya or ghosts of Hinduorigin are found, positing an ambiguity of circumstances where the tales with Islamic overtones are distinctly avoided except for the occasional reference to Faquirs who are more of a roving mendicant like the medieval European pardoner than an active participant in the action of the Folktales. There are also stray linguistic references to European experiences, but these are decidedly non-British in nature like wall-almirah (almirah - from Portuguese. armário) in 'The Story of Swet-Basanta'. The questions about the British colonial empire remain unasked:

What we do not come across are the Sahibs, the Chhoto-lats, the Boxwallas, the Banyas, the Sepoys, the Jemadars and the rest of the Imperial fare. Day's omissions make us ponder - what's so unfolk about the colonial experience after all? Why does a collection of folktales from the late nineteenth century consciously evade references to the one hundred and twenty five years of colonial legacy? How can a late-Victorian collection of folktales of Bengal (which was in many ways the heart of the Empire in India) never breathe a word about its colonial present and past? (Sengupta, 2007)

The sharp transition from the Sultanate to the Company rule and the resultant change in the local administration from an Islamic identifiable form to a distinctly re-invigorated Hindu or neo- Brahmo aristocratic set-up in post- Renaissance Bengal can be observed in the Folktales. The colonial background of education of Day and the clear influences of Bengal Renaissance on his pro-colonial editorial policy is interesting.

The influence of acculturation coupled with the garbed and colonising idea of enlightenment from the pool of irrationality through the dissemination of Anglicised education led him to work untiringly for the spread of Macaulayian idea of education. Lal Behari's decision to omit some of his collected tales as spurious, reflects his attempt to alienate to an extent the debate about colonial Education and Enlightenment that had been widespread both in Europe as well as in India.

The attempt to alienate the audience from the scenario then in vogue, and the harsh realities of colonial rule along with the death and disaster of the epidemics that ravaged Bengal for over a century is questionable to say the least. Folklore is a flow of oral literature born from the realities present around and Day's attempt to shove all the problems of the age under the carpet of romantic reverie stands in stark contrast to Parkes's critical analysis of her experiences and hardships the society faced at large. The insularity of the post-Renaissance 'bhadralok' class in Bengal failed to register any protest during the cholera, fever and sporadic plague epidemics were in full sway. Day's attempt in cataloguing, registering and re-orienting the lore of the land thus at times seem ambiguous.

\section{Conclusion}

The attempt to categorise literary creation based upon social, political, spatial and ideological point of references seems to be misleading at times of general human hardship. The rational, critical apparatus is ineffective at critical historical junctures as it is unable to decipher the humane nature that literature can assume. William Dalrymple (2004), while speaking about Fanny Parkes asserts: 
Parkes is an important writer because she acts as a witness to forgotten moment of BritishIndian hybridity, and shows that colonial travel writing need not be an aggressive act of orientalist appropriation - not "gathering colonial knowledge", as Edward Said and his followers would have us believe, but instead an act of understanding.

Fanny Parkes successfully challenges the binary of colonialism and oriental gaze and creates a coloniser-colonised hybridity or 'chutnification' (Rushdie), to initiate a phase of reversetransculturation: "When she arrived home, her mother barely recognised her. It was as if the current of colonisation had somehow been reversed: the coloniser had been colonised. India had changed and transformed Fanny Parkes. She could never be the same again." (Travel Writing and the Empire, p. 48) However, the attempt to observe and empathize with the masses and evaluate their problems at a critical historical juncture of epidemics that ravaged the country is absent in Lal Behari Day. He not only fails to voice his protest or represent the minimal of hardships that his countrymen faced in nineteenth century Bengal but also represent the socio-cultural interaction and 'crossover' of the times that paved the way for modern multiculturalism.

\section{References}

Chakraborty, D. 'Community, State and the Body: Epidemics and Popular Culture in Colonial India', in D. Hardiman and P. B. Mukharji (eds), Medical Marginality in South Asia: Situating Subaltern Therapeutics. pp 44-46. Routledge.

Chandavarkar, R. (1992). Plague panic and epidemic politics in India, 1896-1914. Epidemics and Ideas, 203240. https://doi.org/10.1017/cbo9780511563645.010

Day, L. B. (1883). Folk-tales of Bengal.(1912 ed.). Macmillan. Online available at https://www.gutenberg.org/ Dalrymple, William. (2007). Lady of the Raj. Guardian, Sat 9, June 2007.

. (2004) Porous Boundaries and Cultural Crossover: Fanny Parkes and "Going Native", in Sachhidananda Mohanty (Ed.) Travel Writing and the Empire. pp 42-62 Katha. . (2003) Begums, Thugs E Englishmen. The Journals of Fanny Parkes. Penguin.

Hamlin, C. (2009). Cholera: The biography (2009 ed.). Oxford University Press.

Harrison, M. (2019). A dreadful scourge: Cholera in early nineteenth-century India. Modern Asian Studies, 54(2), 502-553. https://doi.org/10.1017/s0026749x17001032

Naregal, V. (2001). Language politics, elites, and the public sphere. Orient Blackswan.

Naskar, D. (1999). Chabbish Paganar Loukik Debdebi Palagan-O-Loksanskriti Jignasha. Dey's Publishing.

Parkes, F. (1850). Wanderings of a pilgrim in search of the picturesque. Volume I \& II. Pelham Richardson. Online available at https://www.archive.org/

Sarkar, N.K. (1917) 'Cholera in Calcutta-Its Sanitary and Municipal Conditions from Early Times, Part IV’, Calcutta Medical Journal, XI, 1916-17.

Sengupta, Rangeet. (2007). Bengali folktales in English translation. Lal Behari Day and the discovery of the genuine folk. English Literature Web Sites Essays Books \& Forum. https://www.literature-studyonline.com/essays/bengali-folktales.html

Shri Arijit Goswami is an Assistant Professor in the West Bengal Education Service (WBES), presently posted at Gorubathan Government College which is affiliated to the University of North Bengal. 